\title{
Beech shearing/high-stumping to control understory interference
}

\author{
by Ralph D. Nyland ${ }^{1}$ and Diane H. Kiernan ${ }^{1}$
}

\begin{abstract}
The research evaluated opportunities for cutting off small understory beech root suckers at 0.6-0.9 $\mathrm{m}$ above ground. By six years (pilot test) after cutting with lopping shears in a closed-canopy uneven-aged northern hardwood stand, $91 \%$ of high stumps lacking a residual live branch had died. Of those cut above the lowest living branch, all survived. In a later operational trial by contract crews using chainsaws two growing seasons before a selection system cutting, $75 \%$ of high stumps without a residual live branch had died by the fifth year. Of stumps cut below the lowest living branch and that initially sprouted, only $7 \%$ had a live sprout by the sixth year. Among high stumps cut above the lowest branch, $84 \%$ survived.
\end{abstract}

Key words: understory beech control, cutting beech root suckers, high stumping, beech shearing.

\section{RÉSUMÉ IN TRANSLATION}

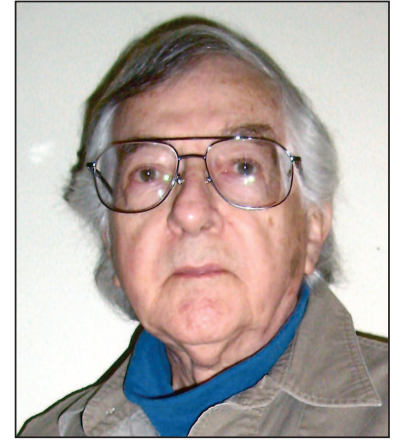

Ralph D. Nyland

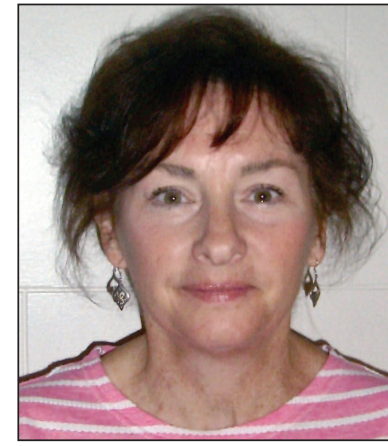

Diane H. Kiernan

\section{Introduction}

Past studies have demonstrated that understory root suckers of American beech (Fagus grandifolia Ehrh.) interfere with the seedlings of other species, resulting in regeneration failures when the suckers form a dense sub-canopy (Bohn and Nyland 2003, Nyland et al. 2006a, 2006b). Herbicide mistblowing in conjunction with shelterwood seed cutting has successfully controlled the interference and resulted in establishment of desirable species in high numbers (Kelty and Nyland 1981, Sage 1987, Ray et al. 1999). Stem injection and basal spraying using glyphosate herbicide have also proven effective in controlling individual beech stems (Kochenderfer et al. 2004, Smallidge and Nyland 2009).

As one alternative for understory beech control we tried prescribed burning in transition oak stands, but only made the situation worse (Adams 1984, Johnson 2000). By necessity, we ignited the fires prior to spring bud break when the trees still had high concentrations of carbohydrates in the root systems. After the surface fires, a high proportion of small beech stems developed multiple stump sprouts and these developed rapidly within the brightened understory. Doing a second dormant season burn after three years did reduce understory beech density to some degree, but not sufficiently to consider the operation a success.

As another alternative to herbicides, early tests using brush saws to cut low stumps during the growing season showed a high degree of control over understory beech (Mallet 2002, Nyland et al. 2006b), as did making simple girdles on trees $\leq$ $7.6 \mathrm{~cm}$ dbh (Nyland 2004). Yet the former requires an important investment in equipment, and neither seem as time efficient as using a basal spray.

Using lopping shears to cut off small beech root suckers at a convenient height (called beech shearing or high-stumping) seemed like one mechanical alternative worth testing. An early Lake States trial that cut aspen (Populus tremuloides

\footnotetext{
${ }^{1}$ Department of Forestry and Natural Resources Management, SUNY College of Environmental Science and Forestry, Syracuse, NY 13210;

* Corresponding author: rnyland@syr.edu
} 
Michx.) and pin cherry (Prunus pennsylvanica L. f.) saplings at $90 \mathrm{~cm}$ above ground during summer resulted in higher stump mortality then cutting them off at $30 \mathrm{~cm}$, with $90 \%$ of high stumps found dead within five years (Stoeckler 1947). More recently in Ontario, using brush saws to cut quaking aspen at a height of 50-75 $\mathrm{cm}$ above ground in summer, but not necessarily below the lowest live branch, resulted in only moderate levels of stem mortality after two years (Bell et al. 1999).

\section{Materials and Methods}

Due to increased interests in finding alternatives to herbicide applications, we had earlier explored traditional brush saw cutting of small beech root suckers from beneath closedcanopy northern hardwood stands. The method effectively killed back most understory root suckers of sapling size (Mallett 2002, Nyland et al. 2006b). Those findings encouraged us to test shearing or high-stumping as another mechanical method for understory beech control. We wondered if cutting high stumps, but below the lowest live branch, might lead to greater mortality of the small understory beech within northern hardwood stands (Fig. 1a and b).

To evaluate cutting high stumps for site preparations we used a 12.1 ha uneven-aged northern hardwood stand in Cuyler Hill State Forest owned and operated by the New York State Department of Environmental Conservation (NYS DEC). In collaboration with NYS DEC, we had managed the stand as a research site using a single-tree selection system, cutting to $17-18 \mathrm{~m}^{2} /$ ha during 1974 and 1993 . Infection by beech bark disease (BBD) during the mid-1970s killed all except a few beech trees larger than $23-25 \mathrm{~cm}$ dbh, and the initial survivors died during early years of the first cutting cycle. Small pole-size beech remained, and these gradually developed into mid-story positions. An understory of root suckers also developed throughout the stand after the incidence of $\mathrm{BBD}$, and the numbers increased in density after each selection system treatment.

\section{A Pilot Test}

During summer 2006, we used heavy-duty lopping shears to test beech root sucker cutting as a site preparation method. At that time the stand had a closed and overlapping cover of foliage on mid- and upper-canopy trees, and with an understory having diameters ranging from $2.5-9.8 \mathrm{~cm} \mathrm{dbh}$. We set out three $30.5 \mathrm{~m}$ wide by $183 \mathrm{~m}$ long test strips within the stand. Then within the strips, our summer research crew sheared off all the small beech at a convenient height, but below the lowest living branch. Generally, they cut the trees at 50-125 cm high (Table 1). This saved the time for bending over and cutting off the root suckers close to ground level. In addition, it meant less fatigue on the workers' lower back. After six years, we checked 20 of the sheared/high stumped understory beech within each of two randomly located transects inside each treated strip, assessing 117 high stumps altogether. We used a minimum of $20.1 \mathrm{~m}$ between sample stumps to reduce chances of evaluating ones off the same parent tree.

\section{An Operational Test}

This same 12.1 ha stand became ready for another selection system treatment by 2010 , and inventory data highlighted the need for site preparation to reduce understory beech interference in order to establish a new cohort of more desirable species. Based on findings from the pilot test of beech shearing, NYS DEC required the contractor to cut off all understory beech, and recommended using the high stump method to facilitate the work. A contractor crew did that shearing during summer 2011 using chainsaws. A selection system treatment followed during 2013, including cutting all beech trees not taken out during site preparation. The combination of cutting within the larger size classes and removing the understory beech left a residual basal area of $17.2 \mathrm{~m}^{2} / \mathrm{ha}$, and a partly open canopy across the stand. This increased groundlevel brightness appreciably.

During summer 2016, we checked high stumps of what had been small-diameter understory beech (mostly $>10 \mathrm{~cm}$ ) cut during summer 2011. We selected two high stumps near each of the 109 permanent regeneration plots that we maintain along a $30.5-\mathrm{x} 30.5-\mathrm{m}$ grid in the stand: one stump cut below the lowest living branch, and one that had a residual living branch. We considered a high stump as living if it had at least one green leaf, even if very small. We also noted the stump type closest to the regeneration plot centre, thereby providing a nearest neighbour assessment to indicate the frequency of stump types throughout the stand. For each high stump, we measured the height and top diameter, and noted the presence of a living residual branch, new shoot, or stump sprout. We calculated frequencies for living or dead stumps between the two types, and did simple tests of significance to assess similarity of stump heights and diameters.

The sampling revealed that some high stumps cut below the lowest live branch had a post-treatment sprout that still had at least one green leaf through five years. To assess the long-term potential, we located such stumps along a random transect through the stand during August of 2017. We looked only for sprouted high stumps cut below the lowest living branch, and noted the position of the sprout and if it remained alive into the sixth year.

\section{Results}

With the pilot test for cutting high stumps, we observed a variation in stump heights between transects but no relationship between stump height and mortality. Of those that had no living branch left on the high stump, $91 \%$ had no sprout at the base or along the residual stem. Of the three with a residual live branch, all remained live (Table 1).

In the operational trial, high stumps averaged $6.4 \mathrm{~cm}$ top diameter and $0.76 \mathrm{~m}$ height for ones without a residual live branch, and $5.1 \mathrm{~cm}$ top diameter and $0.85 \mathrm{~m}$ tall for the others. Tests for similarity in heights and diameters revealed significant differences as shown in Table 1. Based on the nearest neighbour data, the contractor crew had cut $34 \%$ of the root suckers above the lowest living branch. For this stump type, $84 \%$ remained alive after five years. Among stumps cut below the lowest live branch, $75 \%$ had no live sprout or shoot by the 

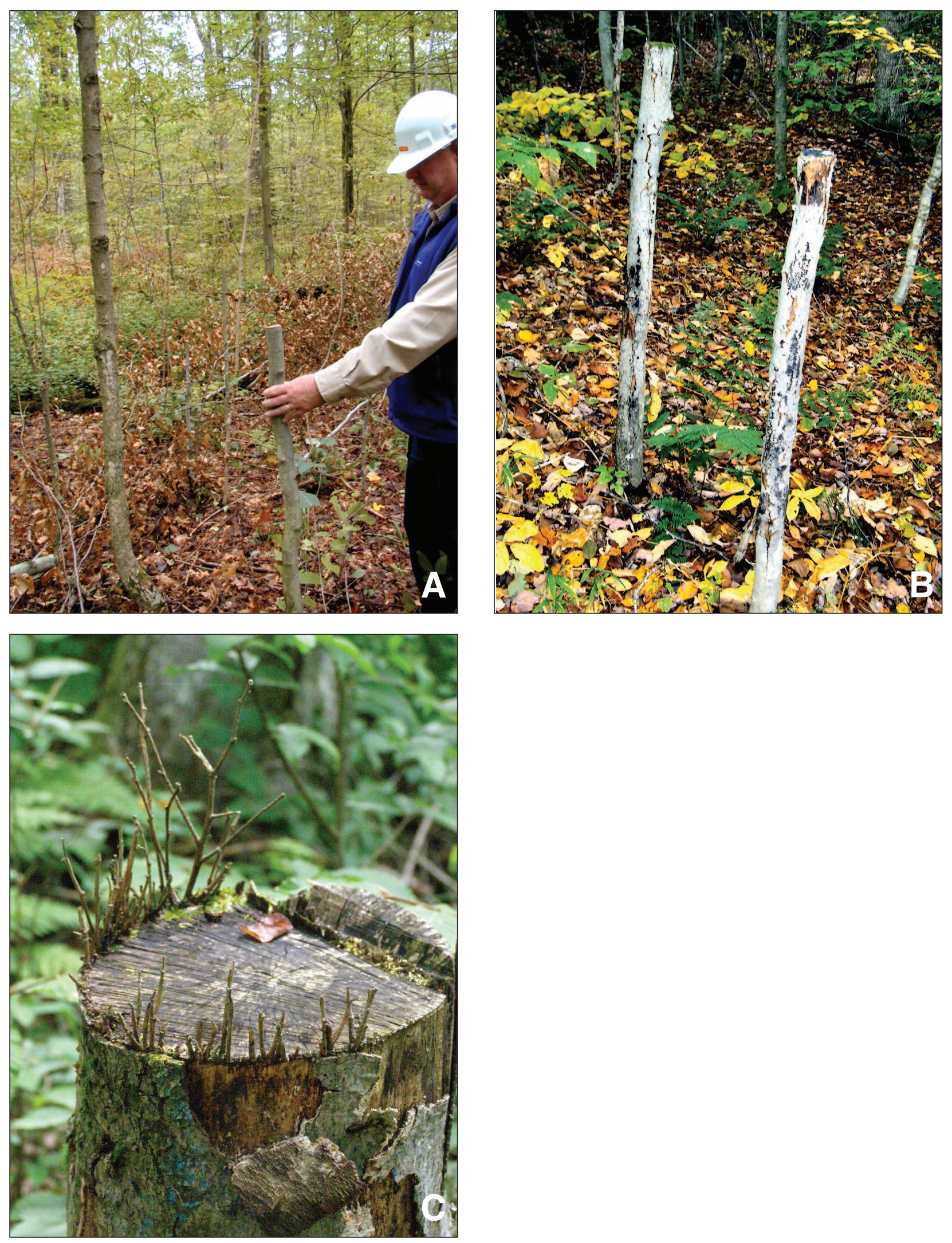

Fig. 1. High-cut stumps of American beech at time of cutting (A), after 6 years (B), and with multiple dead sprouts off the callus rim (C). 
Table 1. Effects of cutting high stumps on survival of understory beech root suckers

Pilot test of beech shearing - cut 2006, sampled 2012

\begin{tabular}{|c|c|c|c|c|c|}
\hline & \multicolumn{2}{|c|}{ Left with no live branch } & \multicolumn{2}{|c|}{ Left with live branch } & \multirow[b]{2}{*}{$\mathbf{p}^{\mathbf{a}}$} \\
\hline & Number & Percent & Number & Percent & \\
\hline Dead & 106 & 91 & 0 & 0 & - \\
\hline Living & 11 & 9 & 3 & 100 & - \\
\hline All & 117 & 100 & 3 & 100 & - \\
\hline Average stump height $-\mathrm{m}(\mathrm{ft})$ & $0.30 \pm 0.28$ & $2.6 \pm 0.93)$ & $1.18 \pm 0.15$ & $.9 \pm 0.49)$ & 0.00 \\
\hline
\end{tabular}

Operational trial of beech shearing - cut in 2011, sampled 2016

\begin{tabular}{|c|c|c|c|c|c|}
\hline & \multicolumn{2}{|c|}{ Left with no live branch } & \multicolumn{2}{|c|}{ Left with live branch } & \multirow[b]{2}{*}{$\mathbf{p}^{\mathbf{a}}$} \\
\hline & Number & Percent & Number & Percent & \\
\hline Dead & 81 & 75 & 17 & 16 & 0.001 \\
\hline Living & 27 & 25 & 91 & 84 & - \\
\hline All & 108 & 100 & 108 & 100 & 0.001 \\
\hline $\begin{array}{l}\text { Average top diameter }-\mathrm{cm}(\mathrm{in} .)^{\mathrm{b}} \\
\text { Average stump height }-\mathrm{m}(\mathrm{ft})^{\mathrm{c}}\end{array}$ & $\begin{array}{l}6.1 \pm 4.67 \\
0.60 \pm 0.1\end{array}$ & $\begin{array}{l}2.5 \pm 1.84) \\
(2.5 \pm 0.52)\end{array}$ & $\begin{array}{l}4.9 \pm 4.01(2 \\
0.85 \pm 0.18\end{array}$ & $\begin{array}{l} \pm 1.60) \\
.8 \pm 0.59)\end{array}$ & $\begin{array}{l}0.040 \\
0.001\end{array}$ \\
\hline
\end{tabular}

Transect through operational trial area - cut in 2011, sampled 2017

\begin{tabular}{lcc} 
& \multicolumn{2}{c}{ Left with no live branch } \\
\cline { 2 - 3 } & Number & Percent \\
\hline Dead & 26 & 93 \\
Living & 2 & 7 \\
\hline All & $\mathbf{2 8}$ & $\mathbf{1 0 0}$
\end{tabular}

aalues in boldface significantly different from the other

${ }^{b}$ For stumps with no residual live branch, the top diameter of dead stumps significantly greater than that of live stumps (0.003). No difference for stumps with a residual live branch 'No significant different in heights between live and dead stumps having a residual live branch or stumps without one.

fifth growing season (Table 1). The remainder mostly had a sprout off the callus rim at the top or a new shoot that emerged some place along the remaining stem.

Along a random transect during the sixth season after cutting, we found 29 sprouted high stumps cut below the lowest live branch (Table 1). Two had a single shoot that emerged along the side of the high stump, and one of these remained alive. We found 26 high stumps where the new shoots emerged around the callus rim at the top, mostly as multiple sprouts (Fig. 1c). Of these, only one high stump (7\%) had a living sprout after six years.

\section{Discussion and Management Implications}

High-stump shearing of understory beech root suckers below the lowest live branch resulted in mortality in most cases (Fig. 1a and b). With earlier brush saw cutting to a low stump (Mallett 2002, Nyland et al. 2006b), we had observed a ring of small and short sprouts that formed in the callus rim around outer edges of the stump top. Most died within three to five years. This also happened with about one-quarter of the high stumps cut below the lowest living branch. Yet about 93\% of these sprouted high stumps had died during the sixth season after cutting, resulting in overall mortality of about 9 of 10 high stumps cut below the lowest living branch. Similarly, among earlier tests in the Lake States, 95\% of all high-cut stumps had died within five years.

By contrast, 8 of 10 stumps cut above the lowest live branch in our treatments remained alive through five growing seasons after treatment. These stumps generally had a single residual live branch of short length and with few leaves. At least with aspen in Ontario, residual branches like these remained alive on surviving stumps, but showed little postcutting growth (Bell et al. 1999). If similar things happen with sheared beech root suckers in our operational trial, the ones that had a live residual branch should not develop sufficiently to interfere with regeneration of other species. In addition, our nearest-neighbour data suggest that such stumps remain at widely dispersed locations, further reducing any possible future impacts.

Our comparisons revealed a significantly greater average height and a significantly smaller top diameter for high-cut beech stumps with a live residual branch. This just supports 
the common sense notion that the higher that workers cut understory beech root suckers above the ground, they will have a smaller diameter stem to sever, but will more likely leave a live residual branch. Data from both of our tests clearly demonstrate the importance of shearing beech root suckers below the lowest live branches.

Consistent with several published sources that evaluated cutting of small hardwood trees, we recommend summertime treatments to minimize the chances that cut stumps will sprout. During the dormant season, carbohydrate reserves have become concentrated in below-ground parts of a tree, and serve as an energy source to support stump sprout development. Hence we recommend delaying cutting until after leaves have fully formed on the trees, and completing the work before dormancy begins to set in after late summer. Between these times, the trees have lower levels of carbohydrates stored in the root systems.

Like earlier observations in the Lake States (Stoeckler 1947), high stumps of trees cut during the 2006 treatment remained firm and solid for 4-5 years (Fig. 1b), and yet by 2013 , we could easily push over a majority of them. Those cut two summers prior to logging in 2013 still remained firm and solid, raising a concern that they might puncture tires of the skidder. To guard against this, the contractor used the fellerbuncher to cut off any high stumps in new skid trails, at an added cost of operations. That suggests a benefit from doing the site preparation at least 4-5 years in advance of a logging operation. Such advance felling of the small beech should also brighten the understory sufficiently to trigger establishment of new seedlings beneath stands with reproductively mature trees in the overstory. Our work with brush saws led to that outcome (Nyland 2006b).

\section{References}

Adams, K.B. 1984. Effects of prescribed fire in transition oak stands in New York. PhD. dissertation. SUNY College of Environmental Science and Forestry, Syracuse, NY.

Bell, F.W., D.G. Pitt, A.E. Morneault and S.M Pickering. 1999. Response of immature trembling aspen to season and height of cut. North. J. Appl. For. 61(2): 108-114.
Bohn, K.K. and R.D. Nyland. 2003. Forecasting development of understory American beech after partial cutting in uneven-aged northern hardwood stands. For. Ecol. and Manage. 180: 453-461.

Johnson, K.S. 2000. Composition of two oak-northern hardwood stands at 18 years after springtime prescribed burning. M.Sc. thesis. SUNY College of Environmental Science and Forestry, Syracuse, NY. Kochenderfer, J.D., J.J. Kochenderfer, D.A. Warner and G.W. Miller. 2004. Preharvest manual herbicide treatments for controlling American beech in central West Virginia. North. J. Appl. For. 23(3): 40-49.

Kelty, M.J. and R.D. Nyland. 1981. Regenerating Adirondack northern hardwoods by shelterwood method. J. For. 79(1): 22-26. Mallet, A.L. 2002. Management of understory American beech by manual and chemical control methods. M.Sc. thesis. SUNY College of Environmental Science and Forestry, Syracuse, NY.

Nyland, R.D. 2004. Simple girdle kills small American beech (Fagus grandifolia Ehrh.). North. J. Appl. For. 21(4): 220-221.

Nyland, R.D., A.L. Bashant, K.K. Bohn and J.M. Verostek. 2006a. Interference to hardwood regeneration in Northeastern North America: Ecologic characteristics of American beech, striped maple, and hobblebush. North. J. Appl. For. 23(1): 53-61.

Nyland, R.D., A.L. Bashant, K.K. Bohn and J.M. Verostek. 2006 b. Interference to hardwood regeneration in Northeastern North America: Controlling effects of American beech, striped maple, and hobblebush. North. J. Appl. For. 23(2): 122-132.

Ray, D.G., R.D. Yanai and R.D. Nyland. 1999. Patterns of early cohort development following shelterwood cutting in three Adirondack northern hardwood stands. For. Ecol. and Manage. 119: 1-11. Sage, R. W., Jr. 1987. Unwanted vegetation and its effects on regeneration success. In: Nyland, R.D. (ed.). Managing northern hardwoods. pp 298-315. SUNY College of Environmental Science and Forestry, Faculty of Forestry Miscellaneous Publication No. 13 (ESF 87-002).

Smallidge, P.S. and R.D. Nyland. 2009. Woodland guides for the control and management of American beech. Smallidge, P. (ed.). Cornell Univ. Coop. Ext. ForestConnect fact sheet.

Stoeckler, J.H. 1947. When is plantation release most effective? J. For. 45(4): 265-271. 